\title{
Komentarz do artykułu A. Ochały i wsp. Coronary-artery bypass grafts angioplasty conducted by 64-multislice spiral computed tomography
}

\author{
Cezary Kępka \\ Klinika Choroby Wieńcowej i Strukturalnych Chorób Serca, Instytut Kardiologii, Warszawa
}

Post Kardiol Interw 2011; 7, 3 (25): 199-200 DOI: 10.5114/pwki.2011.24735

Nowoczesna diagnostyka nieinwazyjna to jeden z gorących tematów w kardiologii. Mało kto z nas może sobie wyobrazić współczesną diagnostykę kardiologiczną bez tomografii komputerowej czy rezonansu magnetycznego. Obecne możliwości tych metod wykraczają - co podkreślają sceptycy - daleko poza generowanie ładnych obrazków. Wystarczy spojrzeć na kolejne edycje zaleceń europejskich czy amerykańskich dotyczących choćby rewaskularyzacji, wad serca $u$ dorosłych czy profilaktyki. W każdym z tych dokumentów zauważono dynamicznie zwiększającą się liczbę dowodów na przydatność tych metod w praktyce klinicznej, co przełożyło się na silniejsze klasy zaleceń. Wydaje się, że na obecnym etapie rozwoju tych metod nie ma już od nich odwrotu. Diagnostyki nieinwazyjnej nie musimy lubić, ale naszym obowiązkiem jest znać jej możliwości i ograniczenia, szczególnie w dobie, gdy każdy (lub prawie każdy) szpital kardiologiczny ma dobrej klasy skanery do tomografii komputerowej i rezonansu magnetycznego. Tomografia komputerowa już kilka lat temu udowodniła bardzo dużą czułość i swoistość w wykluczaniu istotnych zwężeń tętnic wieńcowych i obecnie nieśmiało potwierdza swoją przydatność w diagnostyce pacjentów z już rozpoznaną chorobą wieńcową, w tym w planowaniu rewaskularyzacji.

Współczesny kardiolog interwencyjny coraz częściej spotyka się z pacjentami diagnozowanymi metodami nieinwazyjnymi, co nierzadko wywołuje grymas na twarzy połączony z wypowiedzeniem zwyczajowej formuły typu: „to zróbmy koronarografię, żeby wiarygodnie ocenić tętnice wieńcowe". Takie postępowanie, przy obecnie istniejących dowodach naukowych, często nie jest uzasadnione. Tomografia komputerowa jako metoda pozwalająca na ocenę anatomii tętnic wieńcowych ma obecnie wyższą klasę zaleceń niż tradycyjna koronarografia w diagnostyce mających objawy pacjentów z niskim i pośrednim praw- dopodobieństwem stwierdzenia istotnego zwężenia w tętnicach wieńcowych. Jest jednak kilka warunków, które muszą być spełnione, aby przydatność metody była bliska opisywanej w wielu recenzowanych publikacjach. Podstawowe z nich to: właściwa kwalifikacja do badania, dostęp do odpowiedniego skanera oraz doświadczony zespół lekarski. Jednoczesne spełnienie wszystkich trzech warunków nie jest jeszcze w polskich warunkach częste, ale postęp jest zauważalny.

Cieszy mnie publikacja pracy A. Ochały w Postępach w Kardiologii Interwencyjnej, gdyż uważam, że może ona być przydatna w praktyce klinicznej Czytelników czasopisma. Autorzy podjęli próbę oceny przydatności tomografii komputerowej w kwalifikacji do zabiegów przezskórnej interwencji wieńcowej u pacjentów z objawami po wcześniejszej rewaskularyzacji chirurgicznej. Możliwość optymalnego zaplanowania przezskórnej rewaskularyzacji to jedno z możliwych w przyszłości zastosowań tomografii komputerowej. Obrazowanie pomostów aortalno-wieńcowych jest teoretycznie łatwiejsze niż natywnych tętnic, co wynika głównie z większej średnicy, mniejszej ruchomości i mniejszej liczby zwapnień. Wykonując badanie tomografii komputerowej, należy jednak pamiętać, że naszym celem jest odpowiedź na pytanie, czy pacjent wymaga rewaskularyzacji czy nie. Dlatego istotnym ograniczeniem wspomnianej pracy jest brak analizy natywnych tętnic wieńcowych, również tych, do których nie wszywano wcześniej pomostów, oraz tych, w przypadku których wszyty pomost jest niedrożny. W praktyce brak zwężeń w pomoście i zespoleniach nie wyklucza pacjenta jako potencjalnego kandydata do rewaskularyzacji. Moją uwagę zwróciła również częstość stwierdzania niedrożności pomostów. Z pracy wynika, że średnio $28 \%$ pomostów tętniczych oraz $16,6 \%$ pomostów żylnych w badanej grupie było niedrożnych po około 7,3 roku od operacji. Dziwi nieco bardzo duży 
odsetek niedrożnych pomostów tętniczych, znacznie przewyższający analogiczny odsetek dla pomostów żylnych. Z metodyki nie wynika jednoznacznie, w jakim stanie klinicznym byli analizowani pacjenci (klasa CCS?), być może duża częstość występowania okluzji wynika z charakterystyki grupy.

Warto zauważyć, że u około 30\% (18 z 58) pacjentów po wstępnej kwalifikacji odstąpiono od wykonania tomografii z powodu ograniczeń związanych z badaniem, a u ponad $60 \%$ pacjentów konieczne było podanie $\beta$-adrenolityku. Potwierdza to fakt, że skaner 64-rzędowy nie jest urządzeniem wystarczającym do tego rodzaju diagnostyki. Liczba ograniczeń technicznych, co słusznie zauważyli Autorzy, jest istotnie mniejsza w przypadku urządzeń wyposażonych w detektor o większej liczbie rzędów lub urządzeń dwuźródłowych.

Stopień zawężania światła naczynia, który został uznany przez Autorów za istotny, to $60 \%$ bądź więcej. W większości prac, w których ocenia się czułość i swoistość tomografii komputerowej, granica ta wynosi $50 \%$, co powoduje brak możliwości bezpośredniego porównania wyników uzyskanych przez Autorów z innymi publikacjami. Warto w tym miejscu przypomnieć, że tomografia komputerowa to obecnie metoda jedynie anatomiczna, która nie dostarcza żad- nych informacji o czynnościowej istotności zwężenia, jest więc ona z założenia niewystarczająca dla kwalifikacji pacjenta do rewaskularyzacji. Decyzja taka powinna być podejmowana na podstawie obrazu klinicznego i wyników badań czynnościowych, a obrazy z tomografii komputerowej mogą teoretycznie posłużyć do optymalnego zaplanowania przezskórnej interwencji wieńcowej lub pomostowania aortalno-wieńcowego.

Kwalifikacja (lub dyskwalifikacja) pacjenta do rewaskularyzacji oraz optymalizacja sposobu leczenia to możliwe nowe zastosowania tomografii komputerowej. Gdyby udało się udowodnić przydatność nieinwazyjnej metody, jaką jest tomografia komputerowa, jako podstawowej metody diagnostycznej, należałoby w krótkim czasie spodziewać się istotnej redukcji liczby wykonywanych tradycyjnych koronarografii. Omawiana praca, pochodząca z doświadczonego ośrodka kardiologicznego, jest jedną z pierwszych w Postępach w Kardiologii Interwencyjnej publikacji prezentujących polskie doświadczenia z diagnostyką metodą tomografii komputerowej. Zapewniam wszystkich Czytelników, że warto śledzić postępy tej techniki obrazowej i cieszę się, że czasopismo Postępy w Kardiologii Interwencyjnej, publikując „nieinwazyjne” prace, przyczynia się do edukacji „inwazyjnych” kardiologów. 